\title{
RESENHA
}

\section{A CONSTRUÇÃO SOCIAL DA REALIDADE}

\section{THE SOCIAL CONSTRUCTION OF REALITY}

BERGER, Peter L. LUCKMANN, Thomas. A construção social da realidade: tratado de sociologia do conhecimento. Rio de Janeiro: Editora Vozes, 2004.

\section{Rodrigo da Silva Soares ${ }^{1}$}

Como citar: SOARES, Rodrigo da Silva. A construção social da realidade. Revista do Direito Público, Londrina, v. 12, n. 2, p. 316-319, ago. 2017. DOI: 10.5433/1980-511X.2017v12n2p316

O livro "A construção social da realidade" é uma obra que tem como propósito fazer uma leitura da chamada "Sociologia do Conhecimento". Ele começa exatamente explicando o que seria essa forma de sociologia. Nessa obra, Thomas Luckmann e Peter Berger fazem uma análise do que eles chamam de "processos de legitimação pelos universos simbólicos" que coloca como base do seu pensamento a intersubjetividade e a biografia individual. A grande proposta do livro está na análise de como o homem constrói o seu próprio conhecimento da realidade. Ele trata das relações entre o pensamento humano e o contexto social dentro do qual ele vive. Resumindo o entendimento que os autores têm do que é realidade e conhecimento: a realidade da qual temos consciência, o conhecimento que temos dela, é um produto da sociedade. Essa última construída pelo próprio homem e, por isso, ao

1 Especialista e graduado em Direito pela Universidade Federal do Rio Grande. xrss2006@gmail.com 
mesmo tempo que o homem constrói e molda a sociedade ele é por ela influenciado.

Em seu trabalho os autores abordam o problema da transmissão a uma nova geração das objetivações da ordem institucional que, por sua vez, é tornada como parte inerente e irrefutável da história. Considero a crítica interessante, pois avança na ideia do historicismo marxista. Para eles a legitimação é uma questão de tradição teórica, incluindo também as explicações e justificações.

Esse trabalho explora a questão apresentada do conhecimento (não à toa proposta de se criar uma sociologia do conhecimento) passando por uma abordagem dos aspectos sociológicos da realidade e conhecimento, pela análise dos fundamentos do conhecimento na vida cotidiana, pela análise da sociedade como realidade objetiva e pela análise da sociedade como realidade subjetiva. Esta última claramente a parte mais importante do livro para quem quer fazer um estudo crítico do Direito.

Coexistem diversas realidades, mas a que atua como com maior intensidade na dialética é a realidade da vida cotidiana. A questão relevante abordada diz respeito ao referenciado no título da obra: "A Construção Social da Realidade". A realidade, entendida como fenômenos que existem independentes da nossa vontade, é construída por uma conjunção de fatores sociais, decorrentes da ação humana. A abordagem complementar apresenta a dialética realçada em toda a obra: O homem constrói a realidade social ao mesmo tempo que é por ela influenciado.

Sustentada pela realidade da vida cotidiana, a sociedade se apresenta em duas perspectivas complementares, como realidade objetiva e como realidade subjetiva. A primeira com seus mecanismos básicos 
de institucionalização e legitimação. A segunda a partir de um processo de interiorização da primeira, com seus mecanismos de interiorização, dependente ou não das estruturas sociais.

A conclusão dos autores é tímida, se comparada aos outros pensadores tanto da mesma área quanto de áreas mais gerais que passaram perto de seus temas. Eles dizem que a análise da reificação serve de corretivo padrão para as tendências retificadoras do pensamento teórico em geral, e do pensamento sociológico em particular o que me parece ser uma forma de entender o problema, mas não de mudá-lo na prática. Talvez a prática seja o principal problema da análise feita pelos autores. Algo que incite os leitores a saírem do âmbito do pensamento somente. Até porque a mudança da consciência, como proposta deles, é algo tão subjetivo que tem dificuldade de ser aproveitado na vida real. As estratégias de captura não me parecem suficientes.

Uma questão que merece reflexão ao longo do texto é a do convívio do indivíduo com várias realidades. Embora exista uma realidade supostamente predominante da vida cotidiana, é possível perceber a existência de outras. Dessa forma se explicam as origens de muitos dos conflitos, pois o que pode ser fundamental para o indivíduo não o é para a sociedade. Isso pode ser entendido também em relação às organizações sociais que tem normalmente como maior finalidade a própria sobrevivência.

Um ponto que também não é fechado pelos autores é de onde vem as modificações sociais externas para alterar as configurações sociais da realidade. A construção social de certos processos de mudanças são difíceis de serem encontrados. Como explicar isso visto que, aparentemente, eles não se encaixam na ótica da construção social da realidade devido a fatores externos não implícitos na teoria? O mesmo 
pode ser dito se nos referirmos à subjetividade das pessoas que podem sim ter acesso às reflexões pessoais capazes de modificar suas próprias consequências. A teoria não abarca essas exceções a sua própria realidade.

Como citar: SOARES, Rodrigo da Silva. A construção social da realidade. Revista do Direito Público, Londrina, v. 12, n. 2, p. 316-319, ago. 2017. DOI: 10.5433/1980-511X.2017v12n2p316

Recebido em: 08/08/2017

Aprovado em: 22/08/2017 